\title{
Spectrofluorimetric, Atomic Absorption Spectrometric and Spectrophotometric Determination of Some Fluoroquinolones
}

\author{
Hesham Salem \\ Department of Analytical Chemistry, Faculty of Pharmacy \\ Minia University, Minia, Egypt
}

\begin{abstract}
Simple, accurate, sensitive and selective spectrofluorimetric, atomic absorption spectrometric and spectrophotometric methods are described for the quantitative determination of ten fluoroquinolones (amifloxacin, ciprofloxacin hydrochloride, difloxacin hydrochloride, enoxacin, enrofloxacin, lomefloxacin hydrochloride, levofloxacin, norfloxacin, ofloxacin and pefloxacin mesylate). The first method was a spectrofluorimetric method in which samples of the studied drugs in $0.1 \mathrm{~N} \mathrm{H}_{2} \mathrm{SO}_{4}$ showed native fluorescence at $450 \mathrm{~nm}$ when excitation was at $290 \mathrm{~nm}$. The calibration graph was rectilinear from 0.3-1.4 $\mu \mathrm{g} \mathrm{mL}^{-1}$ (method I). Cobalt sulphate was used for precipitation of the ion associates formed from the reaction with the cited drugs. The formation and solubility of the solid complexes at the optimum conditions of $\mathrm{pH}$ and ionic strength values have been studied. The method depends on direct determination of the ions in the precipitate or indirect determination of the ions in the filtrate by atomic absorption spectroscopy. The optimum conditions for precipitation were carefully studied. Rectilinear calibration graphs were obtained in the range of 3-30 $\mu \mathrm{g} \mathrm{mL}^{-1}$ for each of the investigated drugs. The molar ratios of the formed chelats were determined by Job's method and their association constants were also calculated (method II). Ammonium vanadate was used for the spectrophotometric determination of the selected fluoroquinolones by oxidation in sulphuric acid medium resulting in the development of a greenish blue colour measured at $766 \mathrm{~nm}$ which was attributed to the vanadium (IV) produced by reduction of vanadium (V) by the selected drugs. The optimum conditions for heating time, reagent concentration and sulphuric acid concentration were carefully studied. The accuracy and precision of the proposed method was confirmed by estimating five or six replicates within Beer's law limits were obtained in the range $10-40 \mu \mathrm{g} \mathrm{mL}^{-1}$ for each of the investigated drugs with correlation coefficients not less than 0.9994 for the investigated drugs (method III). The developed spectrofluorimetric, atomic absorption spectrometric and spectrophotometric methods were applied successfully for the determination of the studied drugs in their pharmaceutical dosage forms with a good precision and accuracy compared to official and reported methods as revealed by t-and F-tests. The first method was approximately ten times more sensitive than the second and third methods. Atomic absorption spectrometric method was also applied for the determination of studied drugs in spiked urine and plasma samples.
\end{abstract}

Key words: Fluoroquinolones, Spectrofluorimetry, $0.1 \mathrm{~N} \mathrm{H}_{2} \mathrm{SO}_{4}$, Atomic Absorption Spectrometry, Cobalt Suphate, Spectrophotometry, Ammonium Vanadate, Pharmaceutical Dosage Forms, Biological Fluids

\section{INTRODUCTION}

Quinolones comprise an interesting group of antibacterials whose action is based on their anti-DNA activity. They all possess a carboxylic group in position 3 and a carbonyl group in position 4 , hence they are often referred to as 4-quinolones. Their antibacterial activity is greatly increased by the addition of 6-fluoro and 7-piperazinyl groups to the molecule and named fluoroquinolones. They are the second-generation members of quinolones and are greatly effective against both gram-negative and gram-positive pathogens that are resistant to other antibacterials [1]. The structures of the investigated quinolones are given in Table 1.
Several methods have been reported for the determination of quinolones in pure form, in dosage forms and in biological fluids. Nalidixic acid, norfloxacin, ciprofloxacin and its hydrochloride are official in both USP XXIV [2] and BP 1998 [3], while ofloxacin is official in USP XXIV only. Both USP XXIV and BP 1998 recommend HPLC methods for determination of ciprofloxacin in raw material and in dosage forms. The USP XXIV recommends nonaqueous titration methods for determination of nalidixic acid, norfloxacin and ofloxacin in raw material, while HPLC methods are described for analysis of their dosage forms. The BP 1998 recommends a nonaqueous titration method for determination of nalidixic 
Table 1: Structures of the Investigated Fluoroquinolones<smiles>[R2]c1c(N2CCN([R3])C([R])C2)c(F)cc2c(=O)c(C(=O)O)cn([R7])c12</smiles>

\begin{tabular}{|c|c|c|c|c|}
\hline Compound & $\mathrm{R}_{1}$ & $\mathrm{R}_{2}$ & $\mathrm{R}_{3}$ & $\mathrm{R}_{4}$ \\
\hline Amifloxacin & $\mathrm{NHCH}_{3}$ & $\mathrm{H}$ & $\mathrm{CH}_{3}$ & $\mathrm{H}$ \\
\hline Ciprofloxacin & & $\mathrm{H}$ & $\mathrm{H}$ & $\mathrm{H}$ \\
\hline Difloxacin & $\mathrm{C}_{6} \mathrm{H}_{4}-\mathrm{F}$ & $\mathrm{H}$ & $\mathrm{CH}_{3}$ & $\mathrm{H}$ \\
\hline Enoxacin & $\mathrm{C}_{2} \mathrm{H}_{5}$ & $\mathrm{H}$ & $\mathrm{H}$ & $\mathrm{H}$ \\
\hline Enrofloxacin & & $\mathrm{H}$ & $\mathrm{C}_{2} \mathrm{H}_{5}$ & $\mathrm{H}$ \\
\hline Lomefloxacin & $\mathrm{C}_{2} \mathrm{H}_{5}$ & $\mathrm{~F}$ & $\mathrm{H}$ & $\mathrm{CH}_{3}$ \\
\hline Levofloxacin & & 0 & $\mathrm{CH}_{3}$ & $\mathrm{H}$ \\
\hline Norfloxacin & $\mathrm{C}_{2} \mathrm{H}_{5}$ & $\mathrm{H}$ & $\mathrm{H}$ & $\mathrm{H}$ \\
\hline Ofloxacin & & O & $\mathrm{CH}_{3}$ & $\mathrm{H}$ \\
\hline Pefloxacin & $\mathrm{C}_{2} \mathrm{H}_{5}$ & $\mathrm{H}$ & $\mathrm{CH}_{3}$ & $\mathrm{H}$ \\
\hline
\end{tabular}

acid and norfloxacin in raw material and spectrophotometric method for determination of norfloxacin in dosage forms. Several methods for determination of quinolones including: titrimetric [4-6], spectrophotometric [7-16], spectrofluorometric [17-24], electrochemical [25-27], electrophoretic [28] and chromatographic methods [29-33] were proposed. Several methods including chelation of fluoroquinolones with $\mathrm{Fe}(\mathrm{III})$ [8,13], $\mathrm{Cu}$ (II) [18], $\mathrm{Al}(\mathrm{III})[16,19,22], \mathrm{Mg}$ (II) [16, 19], Ca (II) [16] and $\mathrm{Tb}$ (III) [23] were reported. Most of the analytical methods employed for the determination of the studied drugs in biological fluids are HPLC methods which require complex and expensive equipment, provision for use and disposal of solvents, labour-intensive sample preparation procedure and personnel skilled in chromatographic techniques.

Although atomic absorption spectrometry is a rapid method and has very low detection limits which can not be reached by most of other methods, it has not been applied yet to the determination of these drugs. The present study includes new direct and indirect methods for determination of amifloxacin, ciprofloxacin hydrochloride, difloxacin hydrochloride, enoxacin, enrofloxacin, lomefloxacin hydrochloride, levofloxacin, norfloxacin, ofloxacin and pefloxacin mesylate. The present study represents the utilization of cobalt sulphate as reagent for the determination of the studied drugs by direct and indirect atomic absorption spectrometric measurements.

The spectrofluorimetric, atomic absorption spectrometric and spectrophotometric methods proved to be very sensitive and accurate for the determination of these compounds in bulk powders, in pharmaceutical dosage forms and in biological fluids.

\section{MATERIALS AND METHODS}

Apparatus: $\quad$ Shimadzu recording spectrofluorophotometer. Modl RF-540 (P/N204-02900). Calibrated before use and connected to a printing recorder.

Spectronic ${ }^{\mathrm{TM}}$ Genesys ${ }^{\mathrm{TM}}$, UV/VIS spectrophotometer connected to an IBM computer loaded with the Winspec $^{\mathrm{TM}}$ application software.

A Shimadzu atomic absorption flame spectrophotometer model AA.640-13. For AAS, cobalt was measured at wavelength $240.7 \mathrm{~nm}$, slit width 0.2 $\mathrm{nm}$, relative noise 1.0 , detection limit $0.01 \mu \mathrm{gmL}^{-1}$, lamp current $10 \mathrm{~mA}$ and integration time $3 \mathrm{~s}$. The flame used was the acetylene-air mixture.

The $\mathrm{pH}$ values of solutions were measured using an 
Orion Research Model 601A digital pH-meter.

All calculations were carried out on IBM computer using Microsoft excel 2002 for windows ME. SMAC program [34] was used for all statistical methods.

Materials and Reagents: All solvents and reagents were of analytical reagent grade, double distilled water was used throughout. Samples of fluoroquinolones were generously supplied by their respective manufactures: amifloxacin (Sterling Winthrop Inc., USA); difloxacin hydrochloride (Abbott Laboratories, North Chicago, USA); norfloxacin (Eipico, Cairo, Egypt); pefloxacin mesylate (Rhone-Poulenc Rorer, Neuilly/Seine, France); ofloxacin (Hoechst AG, Frankfurt, Germany); ciprofloxacin hydrochloride (Miles Inc. Pharmaceutical Division, West Haven, Germany); lomefloxacin hydrochloride (Searle, Illinois, USA); enoxacin, enrofloxacin and levofloxacin (Sigma Chem. Co., USA) and were used without further purification. Ammonum vanadate, $5 \% \mathrm{w} / \mathrm{v}$ solution, prepared by dissolving $5 \mathrm{gm}$ in boiling $50 \% \mathrm{v} / \mathrm{v}$ sulphuric acid and diluting to $100 \mathrm{~mL}$ with $50 \% \mathrm{v} / \mathrm{v}$ sulphuric acid and $0.01 \mathrm{M}$ cobalt sulphate $(0.2 \% \mathrm{w} / \mathrm{v}$ solution) were Aldrich products. Sulphuric acid (ADWIC), $0.1 \mathrm{~N}$ and $50 \% \mathrm{v} / \mathrm{v}$ prepared in de-ionized water.

Pharmaceutical Preparations: The following available commercial preparations were analyzed: Spectrama ${ }^{\circledR}$ tablets, Batch No. $814 \quad$ (Amoun Pharmaceutical Industries Co., Cairo, Egypt) labeled to contain $400 \mathrm{mg}$ anhydrous norfloxacin per tablet; Neofloxacin ${ }^{\circledR}$ tablets, Batch No. 151 (Alexandria Co. for Pharmaceuticals, Alexandria, Egypt) labeled to contain $400 \mathrm{mg}$ anhydrous norfloxacin per tablet; Norbactin $^{\circledR}$ tablets, Batch No. 114 (Chem. Ind. Co., Giza, Egypt) labeled to contain $400 \mathrm{mg}$ norfloxacin per tablet; Tarivid ${ }^{\circledR}$ tablets, Batch No. 12 E06 (Hoechst Orient, Cairo, Egypt, under license of Hoechst AG, Frankfurt, Germany) labeled to contain $200 \mathrm{mg}$ ofloxacin per tablet; Kirol $^{\circledR}$ tablets, Batch No. 021269A (Amoun Pharmaceutical Industries Co., Cairo, Egypt) labeled to contain $200 \mathrm{mg}$ ofloxacin per tablet; Mefoxin $^{\circledR}$ tablets, Batch No. 2011 (Misr Co. for Pharmaceutical Industries, Cairo, Egypt) labeled to contain $250 \mathrm{mg}$ ciprofloxacin hydrochloride monohydrate per tablet; Serviflox ${ }^{\circledR}$ tablets, Batch No. 950 (Under Licence from Biochemie Kundi Austria), labeled to contain 250 ciprofloxacin hydrochloride per tablet; Cipro ${ }^{\circledR}$ otic drops, Batch No. 1001111 (Chem. Indus. Develop. Co.,Giza, Egypt) labeled to contain $3.5 \mathrm{mg}$ ciprofloxacin hydrochloride per each $\mathrm{mL}$; Globacin $^{\circledR}$ tablets, Batch No. 18501 (Global Napi Pharm. Egypt) labeled to contain $400 \mathrm{mg}$ pefloxacin in the form of mesylate dihydrate per tablet; Peflacin ${ }^{\circledR}$ ampoules, Batch No. 102 (Rhone-Poulenc Rorer, Neuilly/Seine, France) labeled to contain
$400 \mathrm{mg}$ pefloxacin mesylate dihydrate and $15.3 \mathrm{mg}$ sodium ascorbate per $5 \mathrm{~mL}$ ampoule; Tavanic ${ }^{\circledR}$ tablets, Batch No. 12E07R (Under Licence of Aventis Pharma Germany) labeled to contain $500 \mathrm{mg}$ levofloxacin per tablet.

Standard Preparations: Stock solutions containing 3 $\mu \mathrm{g} \mathrm{mL} \mathrm{m}^{-1}$ of each fluoroquinolone were prepared in ethanol. Working standard solutions for methods I, II and III were prepared by suitable dilution of the stock solutions with ethanol as shown in Table 2.

\begin{tabular}{lll}
\multicolumn{3}{l}{ Table 2: Association Constants of the Formed Chelate } \\
\hline Drugs & Cobalt & \\
& Ass. Const. x $10^{-7}(\mathrm{k})$ & $\log (\mathrm{k})$ \\
\hline Amifloxacin & 125.5894 & 8.9635 \\
Ciprofloxacin $\mathrm{HCl}$ & 110.6514 & 9.0129 \\
Difloxacin $\mathrm{HCl}$ & 142.6511 & 9.0265 \\
Enoxacin & 135.824 & 8.9613 \\
Enrofloxacin & 157.6138 & 9.0589 \\
Lomefloxacin $\mathrm{HCl}$ & 108.9865 & 9.1688 \\
Levofloxacin & 90.9093 & 9.0019 \\
Norfloxacin & 198.0684 & 9.1688 \\
Ofloxacin & 106.9811 & 9.0029 \\
Pefloxacin mesylate & 117.4493 & 9.2500 \\
\hline
\end{tabular}

Average of three determinations

\section{Procedures}

For Spectrofluorimetric Method (Method I): Into a $100 \mathrm{~mL}$ measuring flask, transfer $1 \mathrm{~mL}$ of fluoroquinolones stock solution and complete the volume with $0.1 \mathrm{~N} \mathrm{H}_{2} \mathrm{SO}_{4}$. Different portions of the previous solutions within the concentration range of 3$140 \mu \mathrm{g}$ were diluted to $100 \mathrm{~mL}$ with $0.1 \mathrm{~N} \mathrm{H}_{2} \mathrm{SO}_{4}$. The fluorescence was recorded at $450 \mathrm{~nm}$ with excitation at $290 \mathrm{~nm}$. A blank of $0.1 \mathrm{~N} \mathrm{H}_{2} \mathrm{SO}_{4}$ was measured and the calibration graph was rectilinear from $0.3-1.4 \mu \mathrm{g} \mathrm{mL}^{-1}$.

\section{For Atomic Absorption Spectrometric Method (Method II)}

General Procedure: Aliquots of working standard drug solutions were quantitatively transferred into 25 $\mathrm{mL}$ measuring flasks. To each flask $1.0 \mathrm{~mL}$ of $10^{-2} \mathrm{M}$ standard solution of cobalt sulphate is added and $\mathrm{pH}$ was adjusted to 8.1 using $1 \mathrm{~mL}$ of buffer solution. The solutions are shaken well and left to stand for $15 \mathrm{~min}$ and then filtered through Whatman $\mathrm{P} / \mathrm{S}$ filter paper $(12.5 \mathrm{~cm})$. The precipitate was washed with redistilled deionized water until metal free.

Direct Method: The precipitates obtained above were dissolved in the least amount of dilute acetic acid and complete to $25 \mathrm{~mL}$ with redistilled deionized water. Two $\mathrm{mL}$ of the resulting solution was diluted to $25 \mathrm{~mL}$ with redistilled deionized water.

Indirect Method: The filtrates and washings were collected in $100 \mathrm{~mL}$ volumetric flasks and completed to 
volume with redistilled deionized water. Ten millilitre of the resulting solution was diluted to $100 \mathrm{~mL}$ with redistilled deionized water.

A blank (omitting addition of drugs) was prepared and absorbance was measured at the flaming conditions. Metal concentrations were calculated from a calibration curves.

For Spectrophotometric Method (Method III): To different aliquots of standard drug solution containing $0.2-1.0 \mathrm{mg}$ of the analyzed drugs, $3 \mathrm{~mL}$ of $5 \% \mathrm{w} / \mathrm{v}$ ammonium vanadate was added in a $10 \mathrm{~mL}$ volumetric flask followed by $2 \mathrm{~mL}$ of concentrated sulphuric acid. The mixture was mixed well and boiled gently for 20 min. in water bath, then cooled and diluted to volume with bidistilled water. The absorbance was measured at $766 \mathrm{~nm}$ against blank (omitting the addition of drug).

\section{For Pharmaceutical Preparations}

Procedures for Tablets: An accurately weighed amount, equivalent to $10 \mathrm{mg}$ of each drug from composite of 20 powdered tablets, was transferred into a $100 \mathrm{~mL}$ calibrated flask and diluted to the mark with the appropriate solvent, sonicated for $20 \mathrm{~min}$ and filtered off to obtain solutions of $100 \mu \mathrm{g} \mathrm{mL}^{-1}$. Further dilutions were made to obtain sample solution and then the general procedures were followed.

Procedure for Ampoules: A volume equivalent to 10 mg of each drug was transferred into $100 \mathrm{~mL}$ calibrated flask and diluted to the mark with the appropriate solvent to obtain solution of $100 \mu \mathrm{g} \mathrm{mL} L^{-1}$. Further dilutions were made to obtain sample solution and then the general procedures were followed.

Procedure for Drops: One milliliter of the drops was transferred into a $100 \mathrm{~mL}$ calibrated flask and diluted to the mark with the appropriate solvent to obtain a solution of $30 \mu \mathrm{g} \mathrm{mL}{ }^{-1}$. Further dilutions were made to obtain sample solution and then the general procedures were followed.

Procedure for Determination of Molar Ratio: Drug and cobalt solutions of equimolar concentrations $\left(1 \times 10^{-4} \mathrm{M}\right)$ were prepared. Aliquots of each solution were added in different ratios to a series of $10 \mathrm{~mL}$ calibrated flasks, so that the total volume of both is 5 $\mathrm{mL}$. The $\mathrm{pH}$ is adjusted to 8.1 using $1 \mathrm{~mL}$ buffer solution and then the volume is completed with the appropriated solvent. The relative absorption intensity of each formed chelate is measured at its respective maxima.

\section{Procedures for Biological Fluids}

Urine Treatment: Urine samples were centrifuged at $4000 \mathrm{rpm}$ for $5 \mathrm{~min}$ and then $1 \mathrm{~mL}$ of the clear supernatant was spiked with $1 \mathrm{~mL}$ of the drug stock solution.
Appropriate dilutions were made to obtain solutions in which the drug concentration is 100,300 and $500 \mathrm{ng}$ $\mathrm{mL}^{-1}$ then the atomic absorption spectrometric procedure was followed.

Plasma Treatment: Five milliliter plasma were deproteinized by the addition of $10 \mathrm{~mL}$ acetonitrile, centrifuged at $4000 \mathrm{rpm}$ for $5 \mathrm{~min}$. One milliliter of the clear supernatant was spiked with $1 \mathrm{~mL}$ of the drug stock solution.

The mixture was then extracted with 2 portions; each of $5 \mathrm{~mL}$ chloroform. The chloroformic extract was collected, evaporated on a boiling water bath, then appropriate dilutions were made to obtain drug solutions containing 100,300 and $500 \mathrm{ng} \mathrm{mL}^{-1}$, then the atomic absorption spectrometric procedure was followed.

\section{RESULTS AND DISCUSSION}

Method I: Fluoroquinolones show native fluorescence in water, alcohol, $0.1 \mathrm{~N} \mathrm{NaOH}, 0.1 \mathrm{~N} \mathrm{HCl}$ and $0.1 \mathrm{~N}$ $\mathrm{H}_{2} \mathrm{SO}_{4}$. Solutions of fluoroquinolones in $0.1 \mathrm{~N} \mathrm{H}_{2} \mathrm{SO}_{4}$ exhibited the strongest fluorescence at $450 \mathrm{~nm}$ when excited at $290 \mathrm{~nm}$. A linear correlation was obtained between the fluorescence intensity and concentration in the range 0.3-1.4 $\mu \mathrm{g} \mathrm{mL} \mathrm{m}^{-1}$ and the correlation coefficient was not less than 0.999 . The concentration of different samples of fluoroquinolones in bulk powder and pharmaceutical dosage forms were calculated from the following regression equation:

$\mathrm{C}=0.01261 \mathrm{~F}-0.04213$

Where, $\mathrm{C}$ is the concentration of drug in $\mu \mathrm{g} \mathrm{mL}^{-1}$ and $\mathrm{F}$ is the intensity of fluorescence of drugs at $450 \mathrm{~nm}$ with excitation at $290 \mathrm{~nm}$.

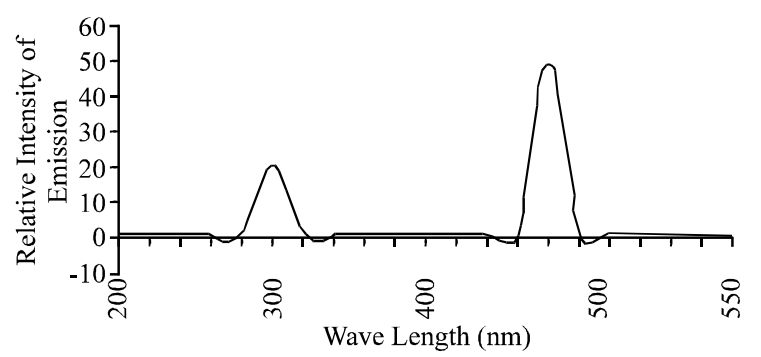

Fig. 1: Excitation and Emission Spectrum of Amifloxacin in $0.1 \mathrm{~N} \mathrm{H}_{2} \mathrm{SO}_{4}$

The native fluorescence of fluoroquinolones is due to the high degree of conjugation found in the structure. Breaking this conjugation was done by adding sodium borohydride $\left(\mathrm{NaBH}_{4}\right)$ to fluoroquinolones aqueous solutions in a molar concentration of $3: 1$, in order to reduce the ketonic group in the pyridine ring. The fluorescence in this case decreased by about 50\% (scheme I). 


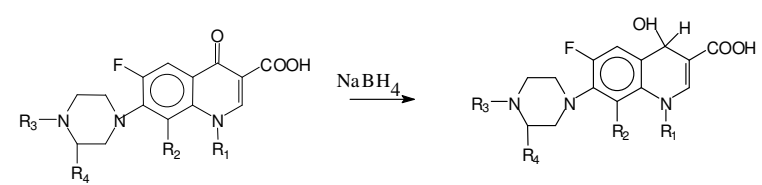

Scheme I

Method II: Also, slightly alkaline (pH 8.1) alcoholic solutions of amifloxacin, ciprofloxacin hydrochloride, difloxacin hydrochloride, enoxacin, enrofloxacin, lomefloxacin hydrochloride, levofloxacin, norfloxacin, ofloxacin and pefloxacin mesylate gave coagulated precipitates with cobalt sulphate. These precipitates form the basis of the micro-quantitative determinations of the cited acidic drugs. Co (II) contents can be determined either directly in the precipitate or indirectly in the filtrate by atomic absorption spectrometry.

Method III: The spectrophotometric method has been used for the quantitative determination of ten fluoroquinolones antibiotics by oxidation with ammonium vanadate in sulphuric acid medium resulting in the development of greenish blue colour at $766 \mathrm{~nm}$ which was attributed to the vanadium (IV) produced by reduction of vanadium $(\mathrm{V})$ by the selected drugs (Fig. 2).

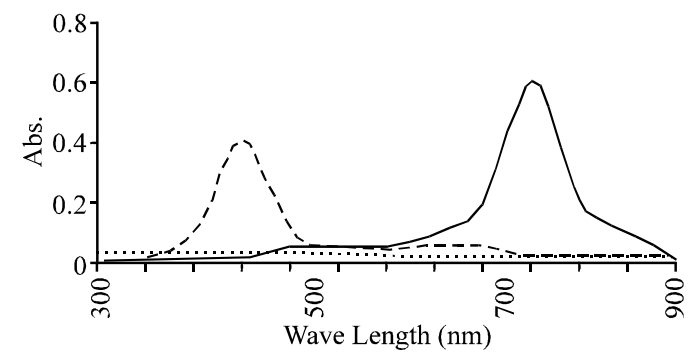

Fig. 2: Absorption Spectra of $0.3 \mathrm{~mL}$ of $1 \mathrm{mg} \mathrm{mL}^{-1}$ Amifloxacin ( $\cdots), 3 \mathrm{~mL}$ of $5 \% \quad \mathrm{w} / \mathrm{v}$ Ammonium Vanadate (- - ) and mixture of them $(-)$

\section{Optimization of the Reaction Conditions}

For Spectrofuorimetric Method (Method I)

Type and Concentration of Reagent: $0.1 \mathrm{~N} \mathrm{H}_{2} \mathrm{SO}_{4}$ exhibited the strongest fluorescence at $450 \mathrm{~nm}$ when excited at $290 \mathrm{~nm}$.

\section{For atomic Absorption Spectrometric Method}

Type and Amount of Alcohol: Addition of the recommended amount of ethyl alcohol is to enhance the solubilization of the drugs and coagulation of the precipitates. Larger volumes of alcohol must be avoided to prevent solubilization of the formed precipitates.

Effect of pH: In order to study the effect of $\mathrm{pH}$ on precipitation, buffer solutions covering the acid to alkaline range were tried. Acid media have a solubilizing effect on the precipitate leading to lower results for the direct technique and higher ones for the indirect technique while higher alkali media precipitate the metal as its oxide or hydroxide leading to higher results for the direct technique. The optimum $\mathrm{pH}$ was found to be slightly alkaline $(\mathrm{pH}=8.1)$.

Metal Concentration: Considering metal ion concentration effect on precipitation, $1 \mathrm{~mL}$ of the precipitating solution was found to be sufficient for complete precipitation.

Temperature: Regarding the temperature effect on precipitation, room temperature was found to be the most efficient. Higher temperature show solubilizing effect on the precipitate producing lower results for the direct technique and higher ones for the indirect technique.

Composition of the Formed Complex: Job's method of continuous variation [35] was used to study the molar ratios of the formed chelates. The method revealed 1:2 ratios for the metal ions (Co (II): quinolone chelates (Fig. 3)). This explains the use of the same optimum metal ion concentration for all the studied drugs.

The stability constants of the formed chelates were calculated using the following equations:

$\beta=\mathrm{A} / \mathrm{A}_{\mathrm{ex}} \mathrm{C}_{\mathrm{X}} /\left(\mathrm{C}_{\mathrm{M}}-\mathrm{A} / \mathrm{A}_{\mathrm{ex}} \mathrm{C}_{\mathrm{X}}\right)\left(\mathrm{C}_{\mathrm{L}}-\mathrm{nA} / \mathrm{A}_{\mathrm{ex}} \mathrm{C}_{\mathrm{X}}\right)^{\mathrm{n}}$

Where, $\beta$ is the stability constant of the formed chelate, $M$ indicates metal, $L$ indicates ligand, $n=X /(1-X)$ where $X$ is the mole fraction of the ligand at the maximum of the continuous variation curve. $\mathrm{A} / \mathrm{A}_{\mathrm{ex}}$ is the ratio of the observed absorbance to that indicated by the tangent for the same wavelength. $\mathrm{C}_{\mathrm{M}}$ and $\mathrm{C}_{\mathrm{L}}$ are the concentrations of the metal and the ligand, respectively, $\mathrm{C}_{\mathrm{x}}=\mathrm{C}_{\mathrm{L}} / \mathrm{n}=\mathrm{C}_{\mathrm{M}}[36]$.

The calculated stability constants for the formed chelates (Table 2) are ranging from $90.9093 \times 10^{7}$ to $198.0684 \times 10^{7}$ indicating good stability of the formed chelates.

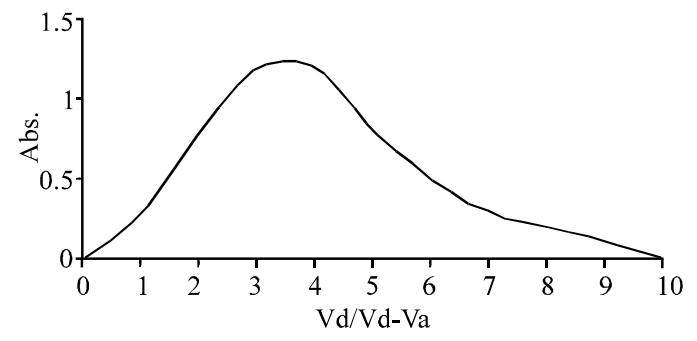

Fig. 3: Job's Curve of Equimolar Solutions of Amifloxacin with Cobalt at the Respective Maxima 
For Spectrophotometric Method (Method III)

Effect of Heating Time:Gentle boiling for 20-30 min. was sufficient to produce maximum colour intensity.

Effect of Reagent Concentration: It was found that 1 $\mathrm{mL}$ of $5 \% \mathrm{w} / \mathrm{v}$ ammonium vanadate was the most suitable concentration for carrying out the assay.

Effect of Sulphuric Acid Concentration: Different concentrations $(10,30,50,70,90$ and $98 \%$ v/v) were tried and it was found that $2 \mathrm{~mL}$ of concentrated sulphuric acid (98\%) gave best results.
Method Validation: The developed spectrofluorimetric, atomic absorption spectrometric and spectrophotometric methods were fully validated according to International Conference on Harmonization guidelines [37] and complied with USP XXIV validation guidelines. The methods were linear over the concentration ranges tested for the used metals. Calibration curves has correlation coefficients (r) higher than 0.999 and coefficients of determinations $\left(\mathrm{r}^{2}\right)$ higher than 0.998 (Table 3) indicating good linearity. Linearity was also checked by calculating the variance of the slope and t-test for the intercept (Table 3).

Table 3: Parameters for Calibration Curves Construction

\begin{tabular}{|c|c|c|c|c|c|c|c|c|c|}
\hline Drugs & Method & $\begin{array}{l}\text { Conc. } \\
\text { range }\left(\mu \mathrm{gL}^{-1}\right)\end{array}$ & $\mathrm{a}$ & $\mathrm{b}$ & $\mathrm{r}$ & $\mathrm{r}^{2}$ & LOD & LOQ & $\begin{array}{l}\text { C.V. } \\
(\%)\end{array}$ \\
\hline \multirow[t]{4}{*}{ Amifloxacin } & I & $0.3-1.0$ & -0.025 & 0.853 & 0.9996 & 0.9992 & 0.125 & 0.322 & 0.58 \\
\hline & II a & $5-25$ & 0.041 & 0.265 & 0.9995 & 0.9990 & 0.024 & 0.251 & 0.49 \\
\hline & $\mathrm{IIb}$ & $5-25$ & 0.265 & 0.705 & 0.9997 & 0.9994 & 1.911 & 0.441 & 0.39 \\
\hline & III & $15-40$ & -1.027 & 0.963 & 0.9996 & 0.9992 & 0.220 & 0.850 & 0.91 \\
\hline Ciprofloxacin & I & $0.4-1.2$ & 0.599 & 0.801 & 0.9994 & 0.9988 & 0.114 & 0.950 & 0.37 \\
\hline \multirow[t]{3}{*}{ Hydrochloride } & IIa & $3-20$ & 1.200 & 0.710 & 0.9995 & 0.9990 & 0.098 & 0.871 & 0.58 \\
\hline & $\mathrm{IIb}$ & $3-20$ & 0.911 & 0.521 & 0.9997 & 0.9994 & 0.211 & 0.747 & 0.80 \\
\hline & III & $10-30$ & 0.588 & 0.456 & 0.9996 & 0.9992 & 1.993 & 0.986 & 0.57 \\
\hline Difloxacin & I & $0.5-1.4$ & 0.635 & 0.574 & 0.9994 & 0.9988 & 0.236 & 0.698 & 0.84 \\
\hline \multirow[t]{3}{*}{ Hydrochloride } & IIa & $6-30$ & 0.666 & 0.158 & 0.9997 & 0.9994 & 0.124 & 0.901 & 0.49 \\
\hline & $\mathrm{IIb}$ & $6-30$ & -0.058 & 0.207 & 0.9997 & 0.9994 & 0.952 & 0.499 & 0.51 \\
\hline & III & $10-35$ & 0.308 & 0.305 & 0.9997 & 0.9994 & 0.997 & 0.745 & 0.29 \\
\hline \multirow[t]{4}{*}{ Enoxacin } & I & $0.2-1.2$ & -1.032 & 0.058 & 0.9995 & 0.9990 & 0.203 & 0.798 & 0.80 \\
\hline & IIa & $5-25$ & 0.870 & 0.157 & 0.9996 & 0.9992 & 0.997 & 0.984 & 0.56 \\
\hline & $\mathrm{IIb}$ & $5-25$ & 0.360 & 0.092 & 0.9996 & 0.9992 & 0.155 & 0.980 & 0.71 \\
\hline & III & $10-30$ & 1.201 & 0.795 & 0.9997 & 0.9994 & 0.201 & 0.379 & 0.55 \\
\hline \multirow[t]{4}{*}{ Enrofloxacin } & I & $0.3-1.2$ & 0.957 & 0.741 & 0.9995 & 0.9990 & 0.908 & 0.981 & 0.81 \\
\hline & IIa & $3-20$ & 1.039 & 0.850 & 0.9996 & 0.9992 & 0.951 & 0.690 & 0.58 \\
\hline & $\mathrm{IIb}$ & $3-20$ & -0.520 & 0.128 & 0.9998 & 0.9996 & 0.195 & 0.920 & 0.61 \\
\hline & III & $10-30$ & 1.520 & 0.361 & 0.9998 & 0.9996 & 0.169 & 0.852 & 0.28 \\
\hline Lomefloxacin & I & $0.5-1.4$ & 0.369 & 0.571 & 0.9995 & 0.9990 & 0.2111 & 0.963 & 0.54 \\
\hline \multirow[t]{3}{*}{ Hydrochloride } & IIa & $5-30$ & 0.661 & 0.548 & 0.9996 & 0.9992 & 0.069 & 0.987 & 0.61 \\
\hline & $\mathrm{IIb}$ & $5-30$ & 0.368 & 0.471 & 0.9995 & 0.9990 & 0.101 & 0.802 & 0.67 \\
\hline & III & $15-40$ & 0.995 & 0.985 & 0.9998 & 0.9996 & 0.992 & 0.556 & 0.58 \\
\hline \multirow[t]{4}{*}{ Levofloxacin } & I & $0.5-1.0$ & 1.254 & 0.399 & 0.9997 & 0.9994 & 0.921 & 0.691 & 0.49 \\
\hline & IIa & $5-25$ & 0.369 & 0.250 & 0.9995 & 0.9990 & 0.120 & 4.631 & 0.51 \\
\hline & $\mathrm{IIb}$ & $5-25$ & -0.058 & 0.668 & 0.9996 & 0.9992 & 0.025 & 0.398 & 0.45 \\
\hline & III & $15-40$ & -0.998 & 0.269 & 0.9995 & 0.9990 & 0.260 & 0.490 & 0.90 \\
\hline \multirow[t]{4}{*}{ Norfloxacin } & I & $0.3-1.4$ & 0.336 & 0.487 & 0.9997 & 0.9994 & 0.000 & 0.588 & 0.89 \\
\hline & IIa & $3-30$ & 0.998 & 0.069 & 0.9996 & 0.9992 & 0.996 & 0.597 & 0.80 \\
\hline & $\mathrm{IIb}$ & $3-30$ & 0.036 & 0.258 & 0.9997 & 0.9994 & 0.030 & 0.459 & 0.60 \\
\hline & III & $10-30$ & 0.914 & 0.398 & 0.9995 & 0.9990 & 0.955 & 0.315 & 0.39 \\
\hline \multirow[t]{4}{*}{ Ofloxacin } & I & $0.2-1.0$ & -1.064 & 0.984 & 0.9997 & 0.9994 & 0.998 & 0.783 & 0.81 \\
\hline & IIa & $3-25$ & 0.287 & 1.005 & 0.9995 & 0.9990 & 0.986 & 0.452 & 0.87 \\
\hline & $\mathrm{IIb}$ & $3-25$ & 0.954 & 0.821 & 0.9996 & 0.9992 & 0.175 & 0.425 & 0.80 \\
\hline & III & $15-35$ & -0.985 & 0.871 & 0.9996 & 0.9992 & 0.125 & 0.851 & 0.49 \\
\hline Pefloxacin & I & $0.3-1.4$ & 1.284 & 0.745 & 0.9995 & 0.9990 & 0.126 & 4.940 & 0.68 \\
\hline \multirow[t]{3}{*}{ Mesylate } & IIa & $3-30$ & 0.782 & 0.489 & 0.9996 & 0.9992 & 0.098 & 0.759 & 0.60 \\
\hline & $\mathrm{IIb}$ & $3-30$ & 0.841 & 0.259 & 0.9998 & 0.9996 & 0.950 & 0.751 & 0.70 \\
\hline & III & $10-40$ & 0.561 & 0.486 & 0.9998 & 0.9996 & 0.049 & 0.763 & 0.81 \\
\hline
\end{tabular}

a: intercept; b: slope; r: correlation coefficient; $\mathrm{r}^{2}$ : coefficient of determination; LOD: limit of detection; LOQ: limit of quantitation; IIa and IIb: Direct and Indirect AAS. 
American J. Applied Sci., 2(3) : 719-729, 2005

Table 4: Statistical Analysis of the Results Obtained Using the Proposed Procedures and Official or Reported Methods for Analysis of Authentic Samples

\begin{tabular}{|c|c|c|c|c|c|}
\hline \multirow[t]{2}{*}{ Drugs } & \multirow[t]{2}{*}{ Method I } & \multicolumn{2}{|c|}{ Method II } & \multirow[t]{2}{*}{ Method III } & \multirow[t]{2}{*}{ Reference method } \\
\hline & & Direct & Indirect & & \\
\hline \multicolumn{6}{|l|}{ Amifloxacin } \\
\hline $\mathrm{X} \pm \mathrm{SD}$ & $99.84 \pm 0.68$ & $99.15 \pm 0.59$ & $99.09 \pm 0.36$ & $99.82 \pm 0.56$ & $99.20 \pm 0.52^{\mathrm{a}}$ \\
\hline $\mathrm{V}$ & 0.46 & 0.35 & 0.13 & 0.32 & 0.27 \\
\hline $\mathrm{t}$ & 1.41 & 0.12 & 0.38 & 1.60 & \\
\hline $\mathrm{F}$ & 1.70 & 1.30 & 2.08 & 1.19 & \\
\hline \multicolumn{6}{|c|}{ Ciprofloxacin hydrochloride } \\
\hline $\mathrm{X} \pm \mathrm{SD}$ & $99.48 \pm 0.51$ & $98.98 \pm 0.50$ & $99.12 \pm 0.46$ & $99.69 \pm 0.66$ & $98.90 \pm 0.52^{b}$ \\
\hline $\mathrm{V}$ & 0.26 & 0.25 & 0.21 & 0.44 & 0.27 \\
\hline $\mathrm{t}$ & 1.16 & 0.22 & 2.29 & 0.47 & \\
\hline $\mathrm{F}$ & 1.04 & 1.08 & 1.29 & 1.63 & \\
\hline \multicolumn{6}{|c|}{ Difloxacin hydrochloride } \\
\hline $\mathrm{X} \pm \mathrm{SD}$ & $99.50 \pm 0.46$ & $99.98 \pm 0.53$ & $99.09 \pm 0.48$ & $98.99 \pm 0.61$ & $100.0 \pm 0.52^{\mathrm{a}}$ \\
\hline $\mathrm{V}$ & 0.21 & 0.28 & 0.23 & 0.37 & 0.27 \\
\hline $\mathrm{t}$ & 1.47 & 0.05 & 0.29 & 0.02 & \\
\hline $\mathrm{F}$ & 1.29 & 1.04 & 1.17 & 1.37 & \\
\hline \multicolumn{6}{|l|}{ Enoxacin } \\
\hline $\mathrm{X} \pm \mathrm{SD}$ & $99.11 \pm 0.66$ & $99.90 \pm 0.59$ & $99.05 \pm 0.46$ & $99.10 \pm 0.66$ & $99.00 \pm 0.62^{a}$ \\
\hline $\mathrm{V}$ & 0.44 & 0.35 & 0.21 & 0.44 & 0.38 \\
\hline $\mathrm{t}$ & 0.24 & 0.21 & 0.14 & 0.22 & \\
\hline $\mathrm{F}$ & 1.16 & 1.09 & 1.81 & 1.16 & \\
\hline \multicolumn{6}{|l|}{ Enrofloxacin } \\
\hline $\mathrm{X} \pm \mathrm{SD}$ & $99.96 \pm 0.58$ & $99.99 \pm 0.59$ & $99.99 \pm 0.66$ & $99.97 \pm 0.69$ & $99.96 \pm 0.63^{\mathrm{a}}$ \\
\hline $\mathrm{V}$ & 0.34 & 0.35 & 0.44 & 0.4 & 0.40 \\
\hline $\mathrm{t}$ & 00.00 & 0.07 & 0.07 & 0.02 & \\
\hline $\mathrm{F}$ & 1.18 & 1.14 & 1.10 & 1.20 & \\
\hline \multicolumn{6}{|c|}{ Lomefloxacin hydrochloride } \\
\hline $\mathrm{X} \pm \mathrm{SD}$ & $99.48 \pm 0.50$ & $99.99 \pm 0.59$ & $99.05 \pm 0.49$ & $99.91 \pm 0.49$ & $100.01 \pm 0.55^{\mathrm{a}}$ \\
\hline $\mathrm{V}$ & 0.25 & 0.35 & 0.24 & 0.24 & 0.30 \\
\hline $\mathrm{t}$ & 1.47 & 0.05 & 0.11 & 0.28 & \\
\hline $\mathrm{F}$ & 1.20 & 0.05 & 0.11 & 0.28 & \\
\hline \multicolumn{6}{|l|}{ Levofloxacin } \\
\hline $\mathrm{X} \pm \mathrm{SD}$ & $99.39 \pm 0.49$ & $99.90 \pm 0.66$ & $99.92 \pm 0.50$ & $99.78 \pm 0.67$ & $100.03 \pm 0.63^{\mathrm{a}}$ \\
\hline $\mathrm{V}$ & 0.24 & 0.44 & 0.25 & 0.45 & 0.40 \\
\hline $\mathrm{t}$ & 1.71 & 0.28 & 0.76 & 0.54 & \\
\hline $\mathrm{F}$ & 1.67 & 1.10 & 1.60 & 1.13 & \\
\hline \multicolumn{6}{|l|}{ Norfloxacin } \\
\hline $\mathrm{X} \pm \mathrm{SD}$ & $99.79 \pm 0.51$ & $99.76 \pm 0.33$ & $99.76 \pm 0.49$ & $100.00 \pm 0.56$ & $100.02 \pm 0.52^{b}$ \\
\hline $\mathrm{V}$ & 0.26 & 0.11 & 0.24 & 0.31 & 0.27 \\
\hline $\mathrm{t}$ & 0.14 & 0.94 & 0.73 & 0.05 & \\
\hline $\mathrm{F}$ & 1.04 & 2.45 & 1.13 & 1.15 & \\
\hline \multicolumn{6}{|l|}{ Ofloxacin } \\
\hline $\mathrm{X} \pm \mathrm{SD}$ & $98.98 \pm 0.46$ & $98.99 \pm 0.57$ & $99.16 \pm 0.65$ & 99.070 .39 & $98.92 \pm 0.57^{b}$ \\
\hline $\mathrm{V}$ & 0.21 & 0.32 & 0.42 & 0.15 & 0.32 \\
\hline $\mathrm{t}$ & 0.17 & 0.17 & 0.54 & 0.47 & \\
\hline $\mathrm{F}$ & 1.52 & 1.00 & 1.31 & 2.13 & \\
\hline \multicolumn{6}{|c|}{ Pefloxacin mesylate } \\
\hline $\mathrm{X} \pm \mathrm{SD}$ & $99.97 \pm 0.51$ & $100.00 \pm 0.60$ & $99.89 \pm 0.51$ & $99.98 \pm 0.46$ & $100.31 \pm 0.50^{\mathrm{a}}$ \\
\hline $\mathrm{V}$ & 0.26 & 0.36 & 0.26 & 0.21 & 0.25 \\
\hline $\mathrm{t}$ & 0.94 & 0.77 & 1.16 & 0.99 & \\
\hline $\mathrm{F}$ & 1.04 & 1.44 & 1.04 & 1.19 & \\
\hline
\end{tabular}

Three and six determinations were used for the reported and the reference methods, respectively. The tabulated values of $\mathrm{t}$ and $\mathrm{F}$ at $95 \%$ confidence limit are $\mathrm{t}=2.23$ and $\mathrm{F}=5.79 .{ }^{\mathrm{a}} \mathrm{USP}$ XXIV, ${ }^{\mathrm{b}}$ Ref. [38] 
American J. Applied Sci., 2(3 ) : 719-729, 2005

Table 5: Assay of the Studied Drugs in Presence of Common Excipients

\begin{tabular}{|c|c|c|c|c|c|}
\hline \multicolumn{6}{|c|}{ Recovery $\% \pm \mathrm{SD}$} \\
\hline Drugs & $\begin{array}{l}\text { Sucrose } \\
10 \mathrm{mg} *\end{array}$ & $\begin{array}{l}\text { Glucose } \\
10 \mathrm{mg}^{*}\end{array}$ & $\begin{array}{l}\text { Starch } \\
5 \mathrm{mg} * \\
\end{array}$ & $\begin{array}{l}\text { Talc } \\
5 \mathrm{mg} * \\
\end{array}$ & $\begin{array}{l}\text { Magnesium stearate } \\
10 \mathrm{mg} *\end{array}$ \\
\hline Amifloxacin & $98.8 \pm 1.2$ & $99.3 \pm 0.96$ & $99.4 \pm 1.0$ & $99.3 \pm 0.8$ & $99.6 \pm 0.75$ \\
\hline Ciprofloxacin & $98.6 \pm 0.9$ & $100.5 \pm 1.0$ & $98.6 \pm 0.8$ & $99.1 \pm 0.6$ & $98.6 \pm 1.4$ \\
\hline Difloxacin & $99.1 \pm 1.3$ & $99.2 \pm 0.6$ & $99.3 \pm 0.8$ & $100.2 \pm 0.8$ & $100.0 \pm 1.3$ \\
\hline Enoxacin & $99.7 \pm 0.9$ & $99.7 \pm 1.3$ & $98.7 \pm 0.6$ & $100.1 \pm 1.2$ & $99.8 \pm 1.1$ \\
\hline Enrofloxacin & $99.2 \pm 0.5$ & $100.4 \pm 1.5$ & $99.9 \pm 1.2$ & $98.9 \pm 0.6$ & $98.8 \pm 1.1$ \\
\hline Lomefloxacin & $99.6 \pm 0.2$ & $99.9 \pm 0.9$ & $99.7 \pm 1.0$ & $98.6 \pm 0.7$ & $98.9 \pm 1.0$ \\
\hline Levofloxacin & $98.9 \pm 0.6$ & $99.8 \pm 1.1$ & $99.3 \pm 0.4$ & $99.2 \pm 0.9$ & $100.8 \pm 0.8$ \\
\hline Norfloxacin & $99.5 \pm 0.9$ & $98.7 \pm 0.4$ & $99.1 \pm 0.8$ & $98.5 \pm 0.2$ & $99.9 \pm 0.8$ \\
\hline Ofloxacin & $99.6 \pm 0.7$ & $98.9 \pm 0.4$ & $99.8 \pm 0.7$ & $98.9 \pm 0.9$ & $99.8 \pm 0.9$ \\
\hline Pefloxacin & $98.9 \pm 1.2$ & $99.7 \pm 1.3$ & $99.8 \pm 0.9$ & $99.7 \pm 1.0$ & $98.7 \pm 0.8$ \\
\hline
\end{tabular}

* The amount of excipients added per $50 \mathrm{mg}$ of drug

Table 6: Determination of Studied Drugs in Their Pharmaceutical Dosage Forms

\begin{tabular}{|c|c|c|c|c|c|c|}
\hline \multirow{2}{*}{\multicolumn{2}{|c|}{ Drugs }} & \multirow[t]{2}{*}{ Method I } & \multicolumn{2}{|c|}{ Method II } & \multirow[t]{2}{*}{ Method III } & \multirow[t]{2}{*}{ Reference method } \\
\hline & & & Direct & Indirect & & \\
\hline \multicolumn{7}{|c|}{ Spectrama $^{\circledR}$ Tablets } \\
\hline & $\mathrm{X} \pm \mathrm{SD}$ & $97.00 \pm 0.66$ & $98.00 \pm 0.70$ & $96.87 \pm 0.62$ & $97.01 \pm 0.75$ & $96.99 \pm 0.69^{\mathrm{a}}$ \\
\hline & $\mathrm{V}$ & 0.40 & 0.49 & 0.38 & 0.56 & 0.48 \\
\hline & $\mathrm{t}$ & 0.02 & 2.04 & 0.27 & 0.04 & \\
\hline & $\mathrm{F}$ & 1.20 & 1.02 & 1.26 & 1.17 & \\
\hline \multicolumn{7}{|c|}{ Neofloxacin ${ }^{\circledR}$ Tablets } \\
\hline & $\mathrm{X} \pm \mathrm{SD}$ & $99.11 \pm 0.59$ & $99.20 \pm 0.61$ & $99.20 \pm 0.59$ & $98.88 \pm 0.61$ & $98.98 \pm 0.60^{b}$ \\
\hline & $\mathrm{V}$ & 0.35 & 0.37 & 0.35 & 0.37 & 0.36 \\
\hline & $\mathrm{t}$ & 0.31 & 0.52 & 0.53 & 0.23 & \\
\hline & $\mathrm{F}$ & 1.03 & 1.03 & 1.03 & 1.03 & \\
\hline \multicolumn{7}{|c|}{ Norbactin ${ }^{\circledR}$ Tablets } \\
\hline & $\mathrm{X} \pm \mathrm{SD}$ & $99.00 \pm 0.90$ & $98.98 \pm 0.91$ & $98.21 \pm 0.91$ & $98.97 \pm 0.78$ & $98.39 \pm 0.85^{\mathrm{a}}$ \\
\hline & $\mathrm{V}$ & 0.81 & 0.83 & 0.83 & 0.61 & 0.72 \\
\hline & $\mathrm{t}$ & 0.03 & 1.04 & 0.29 & 1.03 & \\
\hline & $\mathrm{F}$ & 1.13 & 1.15 & 1.15 & 1.18 & \\
\hline \multicolumn{7}{|c|}{ Tarivid $^{\circledR}$ Tablets } \\
\hline & $\mathrm{X} \pm \mathrm{SD}$ & $100.01 \pm 0.70$ & $99.98 \pm 0.68$ & $99.96 \pm 0.65$ & $99.98 \pm 0.62$ & $99.99 \pm 0.66^{\mathrm{b}}$ \\
\hline & $\mathrm{V}$ & 0.49 & 0.46 & 0.42 & 0.38 & 0.44 \\
\hline & $\mathrm{t}$ & 0.04 & 0.02 & 0.07 & 0.02 & \\
\hline & $\mathrm{F}$ & 1.11 & 1.05 & 1.05 & 1.16 & \\
\hline \multicolumn{7}{|c|}{ Kirol $^{\circledR}$ Tablets } \\
\hline & $\mathrm{X} \pm \mathrm{SD}$ & $100.36 \pm 0.48$ & $99.99 \pm 0.55$ & $100.35 \pm 0.52$ & $100.65 \pm 0.52$ & $100.36 \pm 0.50^{\mathrm{b}}$ \\
\hline & $\mathrm{V}$ & 0.23 & 0.30 & 0.27 & 0.27 & 0.25 \\
\hline & $\mathrm{t}$ & 00.0 & 0.83 & 0.03 & 0.80 & \\
\hline & $\mathrm{F}$ & 1.09 & 1.20 & 1.08 & 1.08 & \\
\hline \multicolumn{7}{|c|}{ Mefoxin ${ }^{\circledR}$ Tablets } \\
\hline & $\mathrm{X} \pm \mathrm{SD}$ & $99.98 \pm 0.54$ & $100.69 \pm 0.48$ & $99.98 \pm 0.56$ & $100.00 \pm 0.55$ & $100.11 \pm 0.49^{b}$ \\
\hline & V & 0.29 & 0.23 & 0.31 & 0.30 & 0.24 \\
\hline & $\mathrm{t}$ & 0.35 & 1.71 & 0.34 & 0.29 & \\
\hline & $\mathrm{F}$ & 1.21 & 1.04 & 1.29 & 1.25 & \\
\hline \multicolumn{7}{|c|}{ Serviflox ${ }^{\circledR}$ Tablets } \\
\hline & $\mathrm{X} \pm \mathrm{SD}$ & $101.12 \pm 0.88$ & $102.00 \pm 0.90$ & $101.98 \pm 0.85$ & $101.98 \pm 0.88$ & $102.00 \pm 0.87^{b}$ \\
\hline & $\mathrm{V}$ & 0.77 & 0.81 & 0.72 & 0.77 & 0.76 \\
\hline & $\mathrm{t}$ & 1.41 & 00.0 & 0.03 & 0.03 & \\
\hline & $\mathrm{F}$ & 1.01 & 1.07 & 1.06 & 1.01 & \\
\hline \multicolumn{7}{|c|}{ Cipro otic ${ }^{\circledR}$ Drops } \\
\hline & $\mathrm{X} \pm \mathrm{SD}$ & $100.01 \pm 0.90$ & $99.95 \pm 0.89$ & $99.98 \pm 0.94$ & $100.12 \pm 0.88$ & $99.88 \pm 0.89^{\mathrm{a}}$ \\
\hline & $\mathrm{V}$ & 0.81 & 0.79 & 0.88 & 0.77 & 0.79 \\
\hline & $\mathrm{t}$ & 0.20 & 0.11 & 0.15 & 0.39 & \\
\hline & $\mathrm{F}$ & 1.02 & 1.00 & 1.11 & 1.03 & \\
\hline
\end{tabular}


American J. Applied Sci., 2(3 ) : 719-729, 2005

Table 6: Continued

\begin{tabular}{|c|c|c|c|c|c|c|}
\hline \multicolumn{7}{|c|}{ Globacin ${ }^{\circledR}$ Tablets } \\
\hline & $\mathrm{X} \pm \mathrm{SD}$ & $99.11 \pm 0.50$ & $99.21 \pm 0.48$ & $98.98 \pm 0.40$ & $99.10 \pm 0.39$ & $99.01 \pm 0.44^{\mathrm{b}}$ \\
\hline & $\mathrm{V}$ & 0.25 & 0.23 & 0.16 & 0.15 & 0.19 \\
\hline $\mathrm{t}$ & $\mathrm{t}$ & 0.29 & 0.60 & 0.10 & 0.32 & \\
\hline $\mathrm{F}$ & $\mathrm{F}$ & 1.32 & 1.21 & 1.19 & 1.27 & \\
\hline \multicolumn{7}{|c|}{ Peflacin ${ }^{\circledR}$ Ampoules } \\
\hline & $\mathrm{X} \pm \mathrm{SD}$ & $99.99 \pm 0.39$ & $100.01 \pm 0.33$ & $99.96 \pm 0.42$ & $99.98 \pm 0.42$ & $100.00 \pm 0.40^{b}$ \\
\hline & V & 0.15 & 0.11 & 0.18 & 0.18 & 0.16 \\
\hline $\mathrm{t}$ & $\mathrm{t}$ & 0.04 & 0.04 & 0.13 & 0.07 & \\
\hline $\mathrm{F}$ & $\mathrm{F}$ & 1.07 & 1.45 & 1.13 & 1.13 & \\
\hline \multicolumn{7}{|c|}{ Tavanic $^{\circledR}{ }^{\Gamma}$ Tablets } \\
\hline & $\mathrm{X} \pm \mathrm{SD}$ & $99.80 \pm 0.50$ & $99.25 \pm 0.49$ & $99.52 \pm 0.63$ & $99.52 \pm 0.54$ & $99.52 \pm 0.60^{\mathrm{b}}$ \\
\hline & $\mathrm{V}$ & 0.25 & 0.24 & 0.40 & 0.29 & 0.36 \\
\hline $\mathrm{t}$ & $\mathrm{t}$ & 0.53 & 0.73 & 0.00 & 0.30 & \\
\hline & $\mathrm{F}$ & 1.44 & 1.50 & 1.11 & 1.24 & \\
\hline
\end{tabular}

Three and six determinations were used for the reported and the reference methods, respectively. The tabulated values of $\mathrm{t}$ and $\mathrm{F}$ at $95 \%$ confidence limit are $\mathrm{t}=2.23$ and $\mathrm{F}=5.79 .{ }^{\mathrm{a}} \mathrm{USP} \mathrm{XXIV},{ }^{\mathrm{b}}[38]$

Table 7: Determination of the Studied Drugs in Spiked Urine and Plasma Samples Using Atomic Absorption Spectrometric Method

\begin{tabular}{|c|c|c|c|c|c|}
\hline \multirow[t]{3}{*}{ Drugs } & \multicolumn{3}{|c|}{ Spiked amount (ng mL $\left.{ }^{-1}\right)$} & \multirow{2}{*}{\multicolumn{2}{|c|}{ Spiked plasma sample }} \\
\hline & & \multicolumn{2}{|c|}{ Spiked urine sample } & & \\
\hline & & Direct & Indirect & Direct & Indirect \\
\hline \multirow[t]{3}{*}{ Amifloxacin } & 10 & $99.58 \pm 0.95$ & $99.96 \pm 0.96$ & $99.91 \pm 0.89$ & $100.1 \pm 0.97$ \\
\hline & 30 & $100.56 \pm 0.92$ & $99.98 \pm 0.93$ & $100.95 \pm 0.89$ & $99.98 \pm 1.02$ \\
\hline & 50 & $98.98 \pm 1.00$ & $101.65 \pm 0.89$ & $99.95 \pm 0.98$ & $101.77 \pm 0.95$ \\
\hline Ciprofloxacin & 10 & $99.98 \pm 1.01$ & $99.65 \pm 0.98$ & $99.92 \pm 0.98$ & $99.39 \pm 0.96$ \\
\hline \multirow[t]{2}{*}{$\mathrm{HCl}$} & 30 & $99.98 \pm 0.89$ & $100.01 \pm 0.79$ & $99.96 \pm 0.89$ & $99.39 \pm 0.89$ \\
\hline & 50 & $100.32 \pm 0.99$ & $98.96 \pm 0.90$ & $99.09 \pm 1.02$ & $100.2 \pm 1.01$ \\
\hline Difloxacin & 10 & $99.98 \pm 1.08$ & $99.98 \pm 0.98$ & $99.85 \pm 0.98$ & $99.99 \pm 0.99$ \\
\hline \multirow[t]{2}{*}{$\mathrm{HCl}$} & 30 & $100.87 \pm 1.02$ & $99.95 \pm 1.12$ & $102.01 \pm 1.5$ & $101.51 \pm 1.10$ \\
\hline & 50 & $100.9 \pm 0.59$ & $99.98 \pm 0.84$ & $98.99 \pm 0.94$ & $98.89 \pm 1.02$ \\
\hline \multirow[t]{3}{*}{ Enoxacin } & 10 & $100.91 \pm 0.74$ & $99.92 \pm 0.91$ & $100.09 \pm 0.91$ & $100.01 \pm 0.98$ \\
\hline & 30 & $99.45 \pm 0.87$ & $99.85 \pm 1.00$ & $99.85 \pm 1.30$ & $99.98 \pm 1.00$ \\
\hline & 50 & $101.20 \pm 0.95$ & $99.20 \pm 1.30$ & $99.99 \pm 0.98$ & $99.21 \pm 0.96$ \\
\hline \multirow[t]{3}{*}{ Enrofloxacin } & 10 & $100.1 \pm 0.29$ & $99.95 \pm 0.39$ & $100.90 \pm 0.67$ & $99.01 \pm 0.56$ \\
\hline & 30 & $98.56 \pm 0.96$ & $99.98 \pm 0.95$ & $100.62 \pm 0.98$ & $99.04 \pm 0.69$ \\
\hline & 50 & $101.75 \pm 0.69$ & $99.98 \pm 0.75$ & $100.05 \pm 0.95$ & $99.95 \pm 1.05$ \\
\hline Lomefloxacin & 10 & $98.49 \pm 0.84$ & $99.56 \pm 1.61$ & $101.92 \pm 1.20$ & $99.99 \pm 0.85$ \\
\hline \multirow[t]{2}{*}{$\mathrm{HCl}$} & 30 & $99.96 \pm 0.85$ & $100.02 \pm 0.96$ & $99.98 \pm 0.96$ & $99.99 \pm 1.03$ \\
\hline & 50 & $100.20 \pm 1.10$ & $99.99 \pm 0.98$ & $100.23 \pm 0.98$ & $99.00 \pm 0.39$ \\
\hline \multirow[t]{3}{*}{ Levofloxacin } & 10 & $99.98 \pm 0.39$ & $100.97 \pm 0.99$ & $99.98 \pm 0.69$ & $100.98 \pm 0.98$ \\
\hline & 30 & $101.65 \pm 0.78$ & $98.29 \pm 0.91$ & $99.89 \pm 0.27$ & $99.84 \pm 0.59$ \\
\hline & 50 & $100.65 \pm 0.98$ & $99.26 \pm 1.20$ & $100.96 \pm 0.59$ & $100.45 \pm 0.69$ \\
\hline \multirow[t]{3}{*}{ Norfloxacin } & 10 & $101.26 \pm 0.85$ & $100.95 \pm 1.30$ & $99.99 \pm 0.90$ & $99.69 \pm 0.89$ \\
\hline & 30 & $98.85 \pm 0.84$ & $99.99 \pm 0.59$ & $101.36 \pm 0.89$ & $99.95 \pm 0.89$ \\
\hline & 50 & $99.95 \pm 0.89$ & $101.98 \pm 0.99$ & $100.99 \pm 1.25$ & $99.95 \pm 0.99$ \\
\hline \multirow[t]{3}{*}{ Ofloxacin } & 10 & $98.29 \pm 0.98$ & $100.58 \pm 0.52$ & $98.87 \pm 0.59$ & $100.89 \pm 0.95$ \\
\hline & 30 & $101.52 \pm 0.98$ & $99.98 \pm 0.97$ & $99.69 \pm 1.30$ & $102.00 \pm 1.30$ \\
\hline & 50 & $99.89 \pm 0.59$ & $99.89 \pm 0.75$ & $99.19 \pm 0.96$ & $98.28 \pm 0.95$ \\
\hline Pefloxacin & 10 & $99.32 \pm 0.78$ & $99.31 \pm 1.00$ & $99.89 \pm 0.98$ & $99.20 \pm 0.89$ \\
\hline \multirow[t]{2}{*}{ Mesylate } & 30 & $100.3 \pm 1.90$ & $98.89 \pm 0.98$ & $99.45 \pm 1.41$ & $99.89 \pm 0.90$ \\
\hline & 50 & $101.22 \pm 0.75$ & $99.25 \pm 1.32$ & $99.55 \pm 1.11$ & $98.88 \pm 0.29$ \\
\hline
\end{tabular}

The accuracy of the methods were determined by investigating the recovery of each of the studied drugs at four concentration levels covering the specified range including $100 \%$ of the test concentration (three replicates of each concentration). The results showed excellent recoveries (Table 4). The complete set of validation assays was performed for each drug with the studied metals. The limit of detection (LOD) and limit of quantitation (LOQ) were also determined (Table 3) according to the $\mathrm{JCH}$ guidelines [37], the obtained values indicate the high sensitivity of the proposed methods.

The assay results were unaffected by the presence of excipients as shown by the excellent recoveries 
obtained when analyzing the studied drugs in presence of commonly encountered excipients (Table 5). This fact indicates proper selectivity of the method for determination of the studied drugs in raw material and in their dosage forms. Different parameters affecting the procedures were studied to evaluate robustness; the analytical solutions were stable for at least $24 \mathrm{~h}$ showing reliability of the proposed methods.

Applications: The proposed procedures were applied successfully for determination of the studied drugs in their pharmaceutical dosage forms. Six replicate measurements were made in each case, the results obtained were validated by comparison with well established official and reported methods by means of tand F-tests at 95\% confidence level (Table 6) and no significant difference was found indicating good accuracy and precision.

No interference was observed from commonly used excipients such as starch, talc, glucose, sucrose and magnesium stearate (Table 5). Also, no interference was caused by the presence of sodium ascorbate with pefloxacin in the Pefloxacin ${ }^{\circledR}$ ampoules.

The high sensitivity attained by the atomic absorption spectrometric method allows the determination of the studied quinolones in biological fluids. Therefore, the proposed methods were applied for determination of the studied drugs in spiked samples of human urine and plasma and the recoveries were determined by calibration curve method. Excellent recoveries were obtained at three concentration levels of each drug in both urine and plasma samples (Table 7). The accuracy was assessed by investigating the recovery of each of the studied drugs at three concentration levels covering the specified range (three replicates of each concentration). The results showed excellent recoveries with S.D. less than $2.5 \%$ indicating both good accuracy and precision. Only plasma samples required deproteination and extraction steps while untreated urine samples are processed directly. This indicates that the proposed methods are selective enough to tolerate the presence of common excipients, other active constituents which may be found in different dosage forms (such as sodium ascorbate in Pefloxacin ${ }^{\circledR}$ ampoules) and matrices of biological fluids as urine and plasma. The proposed methods are advantageous than many of the reported spectrophotometric methods for determination of the studied drugs in pharmaceutical dosage forms and in biological fluids. They are also much simpler and less expensive and time consuming than represented HPLC methods.

\section{CONCLUSION}

The proposed spectrofluorimetric, atomic absorption spectrometric and spectrophotometric methods are simple, rapid, selective and highly sensitive. Therefore it is used for determination of the studied drugs either in bulk or in their corresponding dosage forms without interference from commonly used excipients and could be easily used in a quality control laboratory for their analysis.

\section{REFERENCES}

1. Ross, D. L. and C.M. Riley, 1990. Antibacterial effect of nalidixic acid derivatives. Intl. J. Pharm., 63: 237-240.

2. United States Pharmacopoeia 2000. 24, National Formulary 19, US Pharmacopeial Convention, Rockville, M.D.

3. The British Pharmacopoeia 1998. H.M. Stationary Office, London.

4. Kilic, E. F. Koseouglu and M.A. Akay, 1994. Titrimetric analysis of certain flukoroquinolone. J Pharm. Biomed. Anal., 12: 347.

5. Tuncel, M. and Z. Atkoser, 1992. Analytical study of flouroquinolone derivatives. Pharmazie, 47: 642.

6. Baraza, A.M.C. and A. Korolkovas, 1985. Nonaqueous determination of nalidixic acid. Rev. Farm. Bioquim. Univ. Sao Paulo, 21: 141.

7. Saleh, G.A., 1997. Spectropotometric determination of fluoroquinolones. Bull. Phrm. Sci., Assuit University, 20: 27

8. Belal, F., A.A. Al-Majid and A.M. Al-Obaid, 1999. Methods of analysis of 4-quinolone antibacterials. Talanta, 50: 765-86.

9. Sakai, M., A. Hera, S. Anjo and M. Nakamura, 1999. Comparison of the complexation of fluoroquinolone antimicrobial with metal ions by nuclear magnetic resonance spectroscopy. J. Pharm. Biomed Anal., 18: 1057-67.

10. Rizk, M., F. Belal, S.M. and N.M. El-Enany, 2000. A simple kinetic spectrophotometric method for the determination of certain 4-quinolones in drug formulations. Sci. Pharm., 68: 173-88.

11. Sauvaigo, S. T. Douki, F. Odin, S. Caillat, J. Ravanat and J. Cadet, 2001. Analysis of fluoroquinolone photosensitization of 2deoxyguanosine, calf thymus and cellular DNA. Photochem. Photobiol., 73: 230-37.

12. Park, H., C. Oh, H. Lee, J. Lee, K. Yang and K. Bark, 2002. Spectroscopic Properties of fluoroquinolone antibiotics in water-methanol and water acetonitrile mixed solvents. Photochem. Photobiol. 75: 237-48.

13. Altiokka, G., Z, Atkosar and N.O. Can, 2002. The determination of levofloxacin and enoxacin by flow injection using UV detection in pharmaceutical preparations. J. Pharm. Biomed., 30: 881-5.

14. Incilay, S. and T. Ayla, 2002. Spectrophotometric determination of enoxacin as ion-pairs with bromophenol blue and bromocresol purple in bulk and pharmaceutical dosage form. J. Pharm. Biomed., 29: 545-54. 
15. Mostafa, S., M. El-Sadek and E. Awadalla, 2002. Spectrophotometric determination of ciprofloxacin, enrofloxacin and pefloxacin through charge transfer complex formation. J. Pharm. Biomed. Anal., 27: 133-42.

16. Sulu, I. and A. Tamer, 2002. Spectrophotometric determination of enoxacin as ion-pairs with bromophenol blue and bromocresol purple in bulk and pharmaceutical dosage form. J. Pharm. Biomed. Anal., 29: 545-54.

17. Pulgarin, J.A.M., A.A. Molina and P.F. Lopez, 1996. Spectrofluorometric determination of some fluoroquinolones. Talanta, 43: 431.

18. Cordoba-Diaz, M., M. Cordoba-Borrego and D. Cordoba-Diaz, 1998. Modification of fluorescent properties of norfloxac in the presence of certain antacids. J. Pharm. Biomed., 18: 565-71.

19. Diaz, C., M. Cordoba-Borrego and D. CordobaDiaz, 1998. Modification of fluoroscent properties of norfloxacin in the presence of certain antacids. J. Pharm. Biomed. Anal., 18: 565-71.

20. Stankov, M.J., D. Stankov and P. Djurdgevic, 1999. Spectrofluorometric study of some fluoroquinolones. Pharmazie, 54: 73.

21. Juan, A.O.G. and C.M. Manuel, 2000. Spectrofluorometric determination of levofloxacin in tablets, human urine and serum. Talanta, 52: 1149-56.

22. Wu, S., Z. Wujuan, X. Chen., Z. Hu, M. Hooper, H. Martin and Z. Beveley, 2001. Fluorescence characterc antibiotics and cobalt (II) with ATP. Spectrochim. Acta (A), 57: 1317-24.

23. Vilchez, J.L., O. Ballesteros, J. Taoufiki, G. Sanchez-Palencia and A. Navalon. 2001. Determination of the antibacterial norfloxacin in human urine and serum samples by solid-phase spectrofluorimetry. Analytica. Chim. Acta, 444: 279-86.

24. Shuqing, W., W. Zhang, C. Xingguo, H. Zhide, H. Martin, H. Bevely and Z. Zhengfeng, 2001. Fluorescence characteriostic study of the ternary complex of fluoroquinolone antibiotics and cobalt (II) wit ATP. Spectrochim. Acta A, 57: 1317-24.

25. Atkosar Z., G. Altiokka and B. Ergun, 2002. Pulse polargraphic determination of levofloxacin in tablets. Pharmazie, 57: 587-89.

26. Altiokka, G., A. Atkosar and N.O.Can, 2002. The determination of levofloxacin by flow injection analysis using UV detection, potentiometry and conductometry in pharmaceutical preparations. J. Pharm. Biomed. Anal., 30: 881-85.
27. Radi, A. and Z. El-Sherif, 2002. Determination of levofloxacin in human urine by adsorptive squarewave anodic stripping voltammetry on a glassy carbon electrode. Talanta, 58: 319-24.

28. Fierens, C. S. Hillaert and W. Vanden Bossche, 2000. Electrophoretic determination of fluoroquinolones. J. Pharm. Biomed. Anal., 22: 763.

29. Cheng, F. C., T.R. Tsai, Y.F. Chen, L.C. Hung and T.H. Tsai, 2002. Pharmacokinetic study of levofloxacin and ciprofloxacin in rat blood and bile by microanalysis and high-performance liquid chromatography. J. Chromatogr. A, 961: 131-36.

30. Ulrike, N., J. Christian, F. Martin, J. Walter, M. Markus and X. Berhhard, 2002. Simultaneous determination of levofloxacin and ciprofloxacin in microdialysis and plasma by high performance liquid chromatography. Anal. Chimica. Acta, 463: 199-206.

31. Toussaint, B., G. Bordin, A. Janosi and A.R. Rodriguez, 2002. Validation of a liquid chromatography tandem mass spectrometry method for the simulataneous quantification of 11 fluoroquinolone antibiotics in swine kidney. J. Chromatogr. A, 976: 195-206.

32. Cinquina, A.L., P. Roberti, L. Giannetti, F. Longo, R. Draisci, A. Fagiolo and N.R. Brizioli, 2003. Determination of enrofloxacin and its metabolite ciprofloxacin in goat milk by high performance liquid chromatography with diode array detection. J. Chromatogr. A, 987: 221-6.

33. Sinnaeve, T.N., I.J. Decaestecker, P.K. Claerhout, R. Jean-Paul and F. Jan, 2003. Confirmations of ofloxacin precipation in corneal deposits by micrhobore liquid chromotagraphy-quadrupole time of flight tandem mass spectrometery. Tecn. Biomed. Sci., 1: 193-6.

34. Meiere, P.C., R.E. Zund and J. Wiley, 1993. Statistical Methods in Analytical Chemistry (SMAC®).

35. Rose, J., 1964. Advanced Physico-chemical Experimental. Pittman, London, pp: 54.

36. Sawyer, D.T., W.R. Heinman and J.M. Beebe, 1983. Chemistry Experiments for Instrumental Methods. Wiley, New York, pp: 205.

37. Topic Q2B, 1996. Validation of analytical procedures: Methodology. International Conference on Harmonisation (ICH).

38. Salem, H., 2004. Colourimetric and atomic absorption spectrometric determination of some fluoroquinolone derivatives. Sci. Pharm., 72: 51-71. 